\title{
Cigarette smoking and school culture: An analysis of smoking at a high school according to different variables
}

\author{
Cem Gercek ${ }^{1, \mathrm{a}}$ \\ ${ }^{1}$ Faculty of Education, Department of Mathematics and Science Education, Hacettepe University, \\ Ankara, Turkey
}

\begin{abstract}
This research aims to analyse the smoking status of students and teachers at a high school and their mental images in relation to cigarette smoking according to different variables. In this way, it will be possible to be informed of school culture formed about smoking. This is a descriptive research using the survey model. The research group was composed of 537 students attending a high school and 41 teachers. The research data were collected with a form. Data collected were analysed by means of descriptive statistics and Chi-square test. The findings obtained demonstrated that smoking had increased according to grade levels. Accordingly, boys smoked more than girls. $27 \%$ of the teachers were smokers. It was found that teachers as well as students had positive metaphors about smoking. Based on these conclusions, it may be stated that smoking has become a school culture in that school.
\end{abstract}

Keywords: Cigarette smoking, mental image, high school students, teacher, school culture, health education.

\section{Introduction}

Smoking is at the top of harmful habits which are increasing day by day [1, 2]. Cigarette smoking, threatening non-smokers as well as smokers, is one of the considerable factors in millions of people's loss of their life in the world each year. According to World Health Organisation, a person dies of smoking every 13 seconds in the world [3]. Research has shown that passive smoking is as dangerous as smoking $[4,5]$. To exemplify, several diseases such as cardiac diseases, stomach ulcer, COPD (chronic obstructive pulmonary disease), emphysema and cancer can develop in individuals who are exposed to cigarette smoke for 30 minutes.

Tobacco product humans consume the most is cigarette [6]. Studies report that smoking and alcohol drinking is common among young people [7, 8]. Young people's inclination to substance addiction forms prepares the ground for starting smoking, drinking alcohol or using drug. The period when young people try smoking and when they are most biased towards tobacco addiction is adolescence [7]. Adolescence is an important period for

${ }^{\text {a }}$ Corresponding author: cgercek@hacettepe.edu.tr 
physical and cognitive development. Individuals are also psychologically and socially influenced by each other in that period. According to Erikson's Psycho-social Development Theory, individuals experience identity crisis in the period of adolescence [9]. Adolescents are occupied with completing their social roles, status, professional preparation and sexual identity in that period. Individuals experiencing identity crisis have more inclination to substance addiction and smoking is at the leading position in this respect. Young people start smoking at early ages with desire to prove themselves at school or in the circle of friends or in order not to be isolated by their peers. This situation increases the importance of prevention from harmful habits at school $[10,11]$. National approaches are important in struggling with smoking.

According to data coming from the Ministry of Health, approximately one out of ten secondary school students and one out of five high school students smoke [12]. It was found that training at school against smoking (primary prevention training) was effective in refusing smoking and in developing the behaviour of struggling with smoking [13, 14]. Research shows that more than half of the individuals in Turkey smoke at 11 or at an earlier age for the first time $[12,15]$. A study conducted in Turkey found that the number of high male high school students was more than two times as many as female students [16]. Another study found that $64 \%$ of students had smoked at least once in their life [17]. More than half of young people smoked even in provinces having the lowest percentages [12]. This high rate of smoking in young population indicates the necessity for taking precautions. A study performed in the USA with the participation of students reports that the rate of using tobacco products is $6.5 \%$ for secondary school students and $22,9 \%$ for high school students [18].

The risk factors for the youth can be listed as peers, family, stress, misbeliefs and advertisements. An examination of the factor of peers shows that adolescents' need to be accepted by their friends makes them smoke. Friends are as important as families for individuals in adolescence. And friends are sometimes even more important for them [19, 20]. Young people can start smoking because their friends smoke or for such reasons as gaining popularity at school, fear of being isolated from their group of friends, socialising and peer pressure.

As to the factor of family, having parents who are smokers is a factor in starting smoking [21]. Young people can accept their family members as role models in childhood and they can start smoking at very young ages in order to imitate their parents. This is undesirable. Even if young people do not want to try smoking their bias to smoking can increase due to being passive smokers in consequence of having smoking parents. Besides, having smokers in their family reduces young people's age of starting smoking. Apart from that, the rate of smoking also increases as the socio-economic and educational levels of families fall. Parents' inadequate knowledge about child development and their attitudes can also cause their children to have unbalanced and undesired behaviours [9].

Advertisements have undeniable effect on young people in starting smoking. Multinational cigarette companies choose the youth as their audience so as to increase cigarette consumption. The packets of cigarettes are important tools of marketing in increasing cigarette consumption. Incentive advertisements on cigarette packets attract especially young people's attention and encourage them to smoke. The ads on cigarette packets mask the real identity of cigarettes. This puts the youth into great danger. There are scientific studies showing that smoking in movies encourages young people to smoke and thus causes an increase in rates of smoking. Moreover, cigarette producing companies also sponsor events that young people participate in (festivals, concerts, etc.), they focus on the properties of young people's development periods and they aim to give them the impression that smoking provides them with such feelings as excitement, adrenalin, independence, freedom, entertainment and socialising. 
This research is important in that it analyses students' and teachers' smoking at a high school and their mental images about smoking as a whole according to different variables. By determining teachers' and students' mental images about smoking, it will also be possible to be informed of school culture in terms of smoking. Thus, it is thought that important knowledge will be offered in primary prevention activities within this research.

\subsection{Aim of the Research}

This research aims to analyse the smoking status of students and teachers at a high school and their mental images in relation to cigarette smoking according to different variables. In line with this purpose, the research seeks answers to the following questions:

1. 1. What is the smoking status of students according to gender and grade levels?

2. 2. What is the smoking status of teachers?

3. 3. What are the students' and teachers' positive and negative metaphors for smoking and what ae the reasons for this?

\section{Methodology}

This is a descriptive research in survey model. Descriptive studies try to describe actions, groups and institutions in a period of time in terms of "what happens" and "how it happens" [22].

\subsection{Research group}

The research group was composed of 537 students attending a high school in Ankara in 2015-2016 academic year and 41 teachers. Of the students, 307 (57\%) were girls while 230 $(43 \%)$ were boys. 144 of them $(26 \%)$ were the prep class students while $142(26 \%)$ were 9th graders, $128(24 \%)$ were 10th graders, $81(15 \%)$ were 11 th graders and $42(9 \%)$ were 12 th graders. Of the teachers, on the other hand, $26(65 \%)$ were female while $15(35 \%)$ were male.

The data were collected with a form having received the necessary permission. The form consisted of 3 parts. Part 1 contained demographic properties (age, gender, grade level); Part 2 contained smoking status, where they first started smoking, the number of cigarettes smoked a day; and Part 3 contained metaphors about smoking and questions about the reasons.

A meeting was held with the researcher and the teachers during the applications. A 20minute presentation entitled "Smoking and Life" was made in the meeting. 25 slides and 2 videos were presented during the 20 -minute presentation, and then a 10 -minute discussion was held with teachers on "teachers as models" and "smoking prohibition at schools".

\subsection{Data Analysis}

The data were analysed in percentages, frequencies and in Chi-square. The topics discussed in the meeting with teachers were noted down. The notes taken were presented to teachers' confirmation for reliability.

\section{Findings}

Whether or not there were any significant differences between students' smoking status according to grade levels was tested with chi square analysis. 
Because the data for smoking status and grade levels did not have normal distribution, Chi Square test, which was a non-parametric test, was administered. Accordingly, smoking status differed significantly according to grade levels [X2=83.894; sd:16; $<<0.01]$. Thus, smoking increased as the grade level increased (Table1).

Table 1. The distribution of students' smoking status in percentages

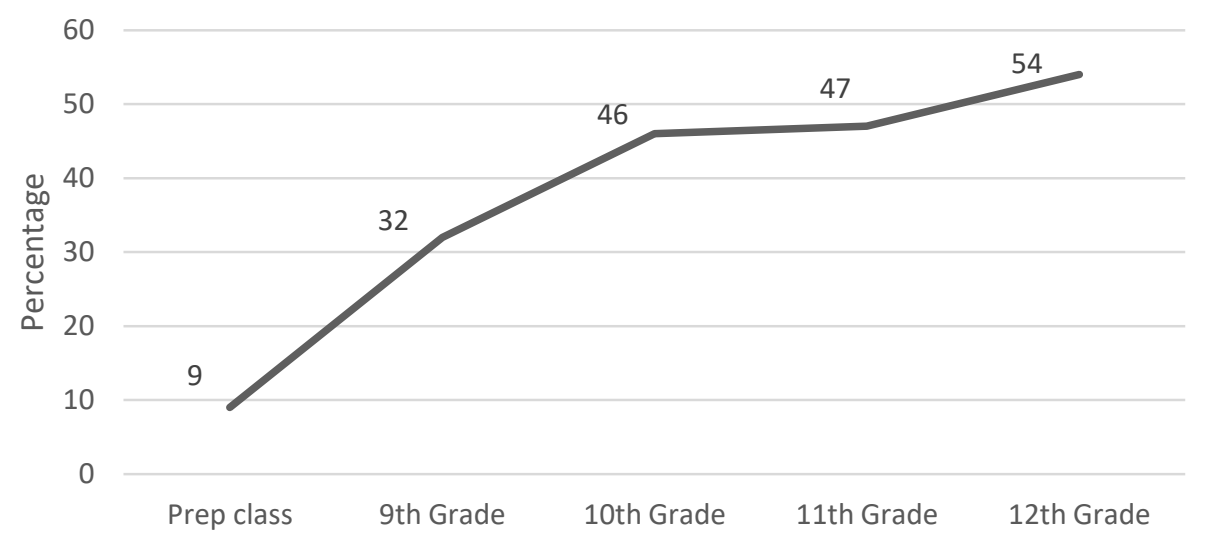

Students' smoking status on the basis of gender was examined in accordance with the first research problem. The issue was analysed with Chi square test- a nonparametric testsince the data did not have normal distribution. Accordingly, smoking status differed significantly according to gender. It was found that boys smoked more than girls [X2=22.010; sd:4; $<<0.01]$.

Detailed examination of students' smoking status according to gender showed that 165 (54\%) of the girls and $109(49 \%)$ of the boys did not smoke. On the other hand, $64(22 \%)$ of the girls and $59(26 \%)$ of the boys said that they smoked. $25(8 \%)$ of the girls and 29 $(13 \%)$ of the boys said that they used to smoke but that they no longer smoked. 528 students in total-305 of whom were girls and 223 of whom were boys- answered this question. In relation to the question about the place where they first smoked, $95(18 \%)$ of the students said that they first smoked at a meeting with friends, $61(11 \%)$ said they first smoked at school, $55(10 \%)$ said they first smoked somewhere else (in the dormitory room, in a relative's house, in the street, on the car) and $35(6 \%)$ said they first smoked at home. In relation to the number of cigarettes they smoked a day, 82 students said that they smoked 12 cigarettes a day on average while 12 students said that they smoked 25 cigarettes a week.

In line with the second research problem, teachers' smoking status was analysed. Accordingly, it was found that 13 teachers (32\%) said that they had never smoked so far, 8 $(19 \%)$ said they had tried smoking once in their life, $7(17 \%)$ said they had smoked occasionally but then gave up smoking, $4(10 \%)$ said they sometimes smoked but fewer than one a day on average, and $7(17 \%)$ said that he/she was a regular smoker- which meant at least one cigarette a day. 2 teachers $(5 \%)$ did not answer the question. 6 teachers smoked 14 cigarettes a day on average whereas 4 teachers smoked 6 cigarettes a week on average.

In line with the third research problem, teachers' and students' metaphors about smoking were analysed, and the reasons for those metaphors were also examined. Table 2 shows the metaphors teachers and students created about smoking. Accordingly, teachers created 5 positive and 19 negative metaphors and one neutral metaphor. Students created 70 positive metaphors, 84 negative metaphors and 8 neutral metaphors. 
Table 2. Metaphors created by teachers and students

\begin{tabular}{|c|c|c|c|}
\hline Metaphors & Positive & Negative & Neutral \\
\hline Teachers & $\begin{array}{l}\text { Friend, hobby, coffee, food, } \\
\text { fruit }\end{array}$ & $\begin{array}{l}\text { Instrument of addiction, hell, } \\
\text { illness, disgusting, hypocrite } \\
\text { people, escape, murderer, joy, } \\
\text { rotten food, heroin, an object with } \\
\text { bad smell, smoke, ash, ash tray, } \\
\text { wood, death, shackle, satan, drug, } \\
\text { poison }\end{array}$ & Nothing \\
\hline Students & $\begin{array}{l}\text { A habit, anti-depressant, } \\
\text { antibiotic, friend, love, fire, } \\
\text { way for escape, organ, } \\
\text { relaxing, dream, gap, tea, } \\
\text { flower, chocolate, change, } \\
\text { child of depression, a break } \\
\text { while studying, confidant, cure } \\
\text { to problems, medicine, pal, } \\
\text { entertainment, eating bread } \\
\text { with salt, bread, adolescents' } \\
\text { addiction, personal belonging, } \\
\text { opportunist, football, passing } \\
\text { fancy, real friend, the sky, a } \\
\text { source for showing off, } \\
\text { fertiliser, smell of a rose, nice, } \\
\text { stylish, life, drink, need, } \\
\text { medicine, human, different, } \\
\text { escape, woman, a break to } \\
\text { empty your mind, coffee and } \\
\text { chocolate, killer dog, reading a } \\
\text { book, mineral water, happiness, } \\
\text { something great, nargile, game, } \\
\text { toy, relaxing, soothing, } \\
\text { insincere friend, art, something } \\
\text { that needs respect, love, } \\
\text { darling, stress ball, water, } \\
\text { music you listen to on your } \\
\text { mobile phone, hopelessness, } \\
\text { sleep, loneliness, tranquiliser, } \\
\text { controlling time, joy }\end{array}$ & $\begin{array}{l}\text { Bitter, alcohol, foolishness, } \\
\text { asphalt, smoke of fire, angel of } \\
\text { death, addiction, bacteria, simple } \\
\text { and aimless, meaningless, } \\
\text { scaffold, error, human, suicide, } \\
\text { poison, dirt, glass, spare time, } \\
\text { harm filling a gap, too deep pool, } \\
\text { monster, lung, tool of murder, } \\
\text { sexual intercourse, mud, } \\
\text { desperation, bank with high } \\
\text { interest rates, garbage, dustbin, } \\
\text { stick crackers, rotten fruit, drum, } \\
\text { excrement, exhaust gas, mouse } \\
\text { poison, unnecessary tool, prison, } \\
\text { damaged lung, illness, mistake, } \\
\text { exhaust gas polluting the air, } \\
\text { thief, disgusting, bad habit, } \\
\text { instrument for committing } \\
\text { suicide, lack of willpower, waste, } \\
\text { paper, sewage, cancer, black hole, } \\
\text { murderer, a deceiving friend, } \\
\text { shroud, handcuffs, polluted air, } \\
\text { polecat, bad, king, gambling, } \\
\text { water well, ash tray, expenditure, } \\
\text { stomachache, germ, hatred, } \\
\text { oxygen, school, ocean, deadly, } \\
\text { being penniless, a deodorant with } \\
\text { bad smell, nonsense, chewing } \\
\text { gum, enemy, slot machine, } \\
\text { steroid, telephone, cliff, drug, } \\
\text { virus, snake, eggs, harm, poison }\end{array}$ & $\begin{array}{l}\text { Chimney, } \\
\text { excuse, I } \\
\text { don't know, } \\
\text { grass, pipe, } \\
\text { willpower, } \\
\text { carstic shape, } \\
\text { soap }\end{array}$ \\
\hline
\end{tabular}

The following are some examples for teachers' reasons for their positive, negative and neutral metaphors:

\begin{tabular}{|l|l|}
\hline Positive & $\begin{array}{l}\text { Having changes sometimes relaxes me. } \\
\text { It relaxes me, it shares my loneliness. } \\
\text { It makes me move away by keeping me busy. }\end{array}$ \\
\hline Negative & $\begin{array}{l}\text { Its smell disturbs me most } \\
\text { It influences an individual while smoking, but then everything is the same. } \\
\text { When I do not smoke, I feel physical deprivation. } \\
\text { Ifeel addicted to and captured by cigarettes } \\
\text { Its smell makes me sick. } \\
\text { I cannot breathe }\end{array}$ \\
\hline Neutral & It means nothing to me. \\
\hline
\end{tabular}


The following are some examples for students' reasons for their positive, negative and neutral metaphors:

\begin{tabular}{|c|c|}
\hline Positive & $\begin{array}{l}\text { The only thing that has not left me alone for } 5 \text { years. } \\
\text { You suffer but you keep loving. } \\
\text { It occasionally moves you away. } \\
\text { I sometimes feel like smoking. } \\
\text { It soothes me. } \\
\text { The thing that likes burning and killing, the only thing that considers me valuable. } \\
\text { It is a need. } \\
\text { Something I use in my spare time. } \\
\text { It makes me forget everything when I am depressed. } \\
\text { You smoke when you like, so it is not complete addiction. } \\
\text { It is beside you when you are bored or when you feel like smoking. } \\
\text { When you inhale, you see its smoke and the smoke takes you to your dreams. } \\
\text { It is very nice. } \\
\text { I like it very much. } \\
\text { It is sweet; it removes stress and helps to focus on something. } \\
\text { You are heated when you approach. } \\
\text { You smoke when are depressed. } \\
\text { It takes away all my problems and ir relaxes me, it also hinders me from putting on } \\
\text { weight. } \\
\text { It has worldwide value. } \\
\text { It is the most beautiful and most relaxing thing in the World. } \\
\text { It is unnecessary, people smoke to gain popularity. } \\
\text { It is always beside me whenever I am bored, whenever I wake up in the middle of a } \\
\text { night, before and after a meal. } \\
\text { It is an excuse for any problem. } \\
\text { Everybody smokes in the circle of friends to show off. } \\
\text { Everybody wants to try smoking, and they think it is stylish. } \\
\text { I enjoy it. } \\
\text { I lose my vital functions unless I smoke. } \\
\text { When you do not have what you feel you need, it replaces them. } \\
\text { You imitate others and you smoke. } \\
\text { People feel as if they were different while smoking. } \\
\text { You like it to be beside you when you want it or need it. } \\
\text { It is something disturbing for those who do not want it but it is something relaxing for } \\
\text { those who want it. } \\
\text { It empties your mind. it takes away all your problems and sorrows. } \\
\text { It is the thing that is beside you when you feel empty and it is the thing that makes } \\
\text { you feel numb. } \\
\text { I cannot do without smoking. }\end{array}$ \\
\hline Negative & $\begin{array}{l}\text { It causes addiction and you cannot quit even if you want to. } \\
\text { It reminds me of the treachery of life. } \\
\text { It is simple but enjoyable death. } \\
\text { Most people start smoking to be accepted by their friends or with their encouragement, } \\
\text { and they cannot say "no". } \\
\text { First it relaxes you, it seems as if it eliminated all your problems. But then causes }\end{array}$ \\
\hline
\end{tabular}




\begin{tabular}{|l|l|}
\hline 2oaste of large amounts of money and health problems. \\
Some foolish children spend their spare time smoking because they have nothing to do. \\
Nobody entering into this darkness can reach the daylight. \\
I sometimes smoked when I was bored, but I saw no benefits of smoking. \\
There is a cure but you sometimes cannot get rid of it. \\
I know it is poisonous and I know what illness it causes. \\
I had a violent cough when I tried smoking, it also tastes bad. \\
Smoking is the most dangerous weapon in the world. \\
Most of the adolescents' smoke just to show off. \\
It separates one from his/her beloved ones around him/her. \\
It affects my physical activities. \\
It is unnecessary and harmful addiction. \\
It is clearly one's attempt at killing oneself. \\
It gives harm to individuals financially and medically. \\
It is harmful in every respect; even trying once can make one feel guilty. \\
It is the starting point of every bad habit (of addiction) \\
You lose something at every inhaling \\
It kills hundreds of people every year.
\end{tabular}

\section{Conclusion and discussion}

Smoking is the behaviour which is believed at childhood and youth that it will make individuals appear more mature and adult. The risky developmental period to start using substances is adolescence and young adult period [23]. Students' smoking status on the basis of gender and grade levels was evaluated in this research in accordance with the first research problem. The results indicated that boys smoked more than girls. Global Youth Tobacco research found that smoking prevalence was higher among male participants than among female participants [12]. Thus, the findings are similar. It may be stated that the rate of smoking rises in parallel to the rise in grade levels. The places where students smoked for the first time were the meeting place with friends, school and other (namely- dormitory, room, relatives' house, streets and car) mostly according to the participants' statements. It was found that students smoked at least 3 cigarettes a day. Having smokers in a family or in the immediate neighbourhood, psycho-social factors, imitation and social pressure play important roles in one's starting smoking [9, 24, 25]. Young people identify their feelings of freedom and independence in particular with smoking.

Gender, age, whether or not family members smoke, family income and circle of friends are important factors in starting smoking [8]. Hence, children learn smoking habit from their parents, peers and social environment [26]. The most important factor in causing addiction to smoking is the social environment and circle of friends in early youth [27]. In addition to that, taking one as a role model, imitation and curiosity also encourage adolescents to smoke. Peer education in activities of struggling with smoking in schools is important for this reason $[11,28]$.

On evaluating teachers' smoking status, it was found that the rate of those who had started smoking and had still been smoking was 3 times as high as the rate of those who had never smoked. It was found that those teachers smoked 14 cigarettes a day on average. 
Research has shown that teaching is a profession in which burnout level is high [29]. This finding makes us think that this is an important factor in starting smoking and in continuing smoking. Teachers stated in meetings with them that they obeyed smoking prohibition in school and in the school garden. However, they said that they smoked during breaks a few metres away outside the school gate. They said that students would not take them as role models even if they saw them smoking. Yet, would it be right to think that students will not take their teachers- who teach that smoking is harmful and forbidden at school- as role models $[30,31]$ after seeing them smoking? Or can we think that what they have learnt will be turned into gains? It should not be forgotten that students are biased to take teachers as role models and that they internalise the behaviours which are displayed rather than the behaviours which are taught. Such factors are important in the formation of school culture in relation to smoking.

It was found that teachers and students had positive and negative metaphors about smoking that students' positive metaphors were fewer than the negative ones but that they were more than they should be. Teachers' reasons for their positive metaphors were as in the following: relaxing in a different way, sharing their loneliness and moving them away by keeping them busy. Students' reasons included the following: soothing, eliminating stress, making happy, being an instrument of focusing and controlling, removing the problems/sorrows, hindering putting on weight, being a life style and confidant. Students' statements such as "it has worldwide value", "it is the most beautiful and relaxing thing in the world", when I do not have what I feel I need, it replaces them", "it is the thing which is beside me when I feel empty and it is the thing that makes me feel numb", "it is a therapy at hard times" were important. Teachers' and students' negative statements such as "its smell disturbs me most", "I feel addicted to and captured by it", "we cannot breathe", you cannot give up once you start smoking", "it is simple and enjoyable death", "first it relaxes you, it seems as if it eliminated your problems. But then causes waste of large amounts of money and health problems", "I sometimes smoked when I was bored but I saw no benefits of smoking" there is a cure but you sometimes cannot get rid of I", "it gives harm without making you feel", and "although smoking has no benefits, young people smoke because they imitate others and smoking is deceptive" show that they have adequate knowledge about the issue. Studies conducted also demonstrated that smokers and non-smokers were knowledgeable about smoking [32, 33, 34].

\section{References}

1. H.-W. Huang, C.-C. Lu, Y.-H. Yang, C.-L. Huang, Smoking Behaviours of adolescents, influenced by smoking of teachers, family and friends. Int. Nursing Review, 61, 220-227 (2014).

2. M. O. Raji, H. Muhammad, A. M. Usman, U. Muwafaq, R. A. Oladigbolu, A. U. Kaoje, Cigarette smoking among out-of-school adolescents in sokoto metropolis, North-West Nigeria. Health Science Jounal, 11(3), 1-10 (2017)

3. World Health Organization [WHO], Health for the World's adolescents: a second chance in the second decade. Geneva, Switzerland: WHO Document Production Services (2014).

4. R.R. Kipping, R.M. Campbell, G. J. MacArthur, D.J. Gunnell, M. Hickman, Multiple risk behaviour in adolescence. J. of Public Health, 34(S1) (2012).

5. C.Y. Lovato, C. Zeisser, H. S. Campbell, A. W. Watts, P. Halpin, ... K. S. Brown, Adolescent smoking: effect of school and community characteristics. American Journal of Preventive Medicine, 39(6), 507-514 (2010). 
6. T. Ortabag, S.Ozdemir, B. Bakir, N.Tosun, Health promotion and risk behaviors among adolescents in Turkey. J. School Nursing, 27(4), 304-31 (2011).

7. B. Challier, N. Chau, R. Prédine, M.Choquet, B. Legras, Associations of family environment and individual factors with tobacco, alcohol, and illicit drug use in adolescents. Eur. Journal Epidemiology, 16, 33-42 (2000).

8. O. S. Icmeli, H.Turker, B. Gundogus, M. Ciftci, U. Aka Akturk, Behaviours and opinions of adolescent students on smoking. Tuberculosis and Thorax, 64(3), 217-222 (2016).

9. S. A. McLeod, E. Erikson. Retrieved 24 April 2016 from www.simplypsychology.org/Erik-Erikson.html (2013).

10. O. O. Adeyeye, Cigarette smoking habits among senior secondary students in Lagos, Southwest Nigeria. Int. J. Medicine Research, 2, 1047-1050. (2011).

11. H. J. Paek, T. Hove, H. J. Oh, Multilevel analysis of the impact of school-level tobacco policies on adolescent smoking: the case of Michigan. J. of School Health, 83(10), 679-689 (2013).

12. Ministry of Health, Küresel yetişkin tütün araştırması türkiye raporu. [Global adult tobacco survey: Turkey report], (Report No: 943). Retrieved April 15, 2016 from http://www.halksagligiens.hacettepe.edu.tr/KY-TA_TR.pdf (2012).

13. H. Beckmann, S.Mechnich, Kinder vor dem Rauchen schützen [Protect children from smoking]. Frankfurt: Fischer Taschenbuch Verlag GmbH (2001).

14. A. Beelmann, B. Thomas, Wirksamkeit von Präventionsmaßnahmen bei Kindern und Jugendlichen [Effectiveness of preventive measures in children and adolescents]. Zeitschrift für Klinische Psychologie und Psychotherapie, 35(2), 151-162 (2006).

15. G. Emekdar, R. Çıtıl, Y. Önder, Y. E. Bulut, Ö. Yaşayancan, N., Ö Kazancı, E. Sönmezgöz, M. Eğri, Smoking prevalence and related factors among secondary and high school students in tokat province. J. of Contempporary Medicine, 7(1), 58-56 (2017).

16. D. Dogan Gumuş, B. Ulukol, Factors contributing to smoking and efficiency of two different education models among adolescents. J. of Inonu University School of Medicine, 17(3), 179-185 (2010).

17. M. Bektas, C. Ozturk, Development of smoking prevention program and evaluation of the program effectiveness. Buca Faculty of Education Journal, 34, 1-21 (2012).

18. S. R. Dube, R. A. Arrazola, J. Lee, M. Engstrom, A. Malarcher, Pro-Tobacco Influences and susceptibility to smoking cigarettes among middle and high school students-United States, 2011. J. of Adolescent Health, 52(S5), 45-51 (2013).

19. H. Darling, A. I. Reeder, S. Williams, R. McGee, Is there a relation between school smoking policies and youth cigarette smoking knowledge and behaviors? Health Ed. Res., 21(1), 108-115 (2006).

20. M. Kleinjan, R. Engels, J. van Leeuwe, J. Brug, R. van Zundert, R. van den Eijnden, Mechanisms of adolescent smoking cessation: roles of readiness to quit, nicotine dependence, and smoking of parents and peers. Drug \& Alcohol Dependence, 99(1-3), 204-214 (2009).

21. A.B. Albers, L. Biener, M. Siegel, D. M. Cheng, N. Rigotti, Household smoking bans and adolescent antismoking attitudes and smoking initiation: findings from a longitudinal study of a Massachusetts youth cohort. American J. of Public Health, 98(10), 1886-1893 (2008). 
22. J. W. Creswell, Araştırma deseni. [Research Design] (Ed. Selçuk Beşir Demir) Ankara: Egiten Kitap (2013).

23. J. L. Johnson, P. A. Ratner, R. S. Tucker, J. L. Bottorff, B. Zumbo, K. M. Prkachin, J. Shoveller, Development of a multidimensional measure of tobacco dependence in adolescence. Addictive Behaviors, 30(3), 501-515 (2005).

24. L. M. O'Brien, M. Polacsek, P. B. MacDonald, J. Ellis, S. Berry, M. Martin, Impact of a school health coordinator intervention on health-related school policies and student behavior. J. of School Health, 80(4), 176-185 (2010).

25. C. M. Sabiston, C. Y.Lovato, R.Ahmed, A. W.Pullman, V. Hadd, H. S. Campbell, C. Nykiforuk, K. S. Brown, School smoking policy characteristics and individual perceptions of the school tobacco context: are they linked to students' smoking status? J. of Youth Adolescence, 38(10), 1374-1387 (2009).

26. D. Piontek, A.Buehler, U. Rudolph, K. Metz, C. Kroeger, S. Gradl, S. Floeter, C. Donath, Social contexts in adolescent smoking: does school policy matter? Health Edu. Res., 23(6), 1029-1038 (2008).

27. M. Virtanen, M. Pietikainen, M. Kivimaki, J. Luopa, J. Jokela, M. Elovainio, J.Vahtera, Contribution of parental and school personnel smoking to health risk behaviours among Finnish adolescents. BMC Pub. Health, 9, 382-390 (2009).

28. T. A. Barnett, L.Gauvin, M. Lambert, J. O’Loughlin, G.Paradis, J. J. McGrath, The influence of school smoking policies on student tobacco use. Archives Pediatrics \& Adolescent Medicine, 161(9), 842-848 (2007).

29. B. Byrne, The Nomological Network of Teacher Burnout: A Literature Review and Empirically Validated Model. In R. Vandenberghe and A. Huberman (Eds.), Understanding and Preventing Teacher Burnout: A Sourcebook of International Research and Practice (The Jacobs Foundation Series on Adolescence, pp. 15-37). Cambridge: Cambridge University Press (1999).

30. D. Jourdan, J. Pommier, F. Quidu, Practices and Representations of Health Education among Primary School Teachers. Scandinavian J. of Public Health, 38, 86-94 (2010).

31. S. A. Myers-Clark, S. E. Christopher, Effectiveness of a health course at influencing preservice teachers' attitudes toward teaching health. J. of School Health, 71(9). 462466 (2001).

32. P. L. Chen, W. G. Huang, K. Y. Chao, Susceptibility to initiate smoking among junior and senior high school nonsmokers in Taiwan. Preventive Medicine, 49(1), 58-61 (2009).

33. M. Dobbins, K. DeCorby, S. Manske, E. Goldblatt, Effective practices for schoolbased tobacco use prevention. Preventive Medicine, 46(4), 289-297 (2008).

34. B. R. Flay, The promise of long-term effectiveness of school-based smoking prevention programs: a critical review of reviews. Tobacco Induced Diseases, 5(1), 7 (2009). 